\title{
THE 2015 NATIONWIDE REFERENDUM IN POLAND IN MEMES
}

\author{
Maria Marczewska-Rytko \\ Maria Curie Skłodowska University in Lublin, Faculty of Political Science
}

\begin{abstract}
The aim of the article is to analyze memes associated with the nationwide referendum of 6 September 2015 in Poland. The memes are treated as part of the media discourse. Media discourse encompasses part of public discourse. In the broad sense, we are dealing with a collection of statements functioning in the public space and concerning a specific problem or its scope. There will be analyzed memes connected such issues as the reason/reasons for ordering the referendum, referendum questions, the financial costs incurred, and the referendum turnout. The article is divided into two parts: 1) theoretical consists of mem and referendum definition; 2) practical consists of the 6 September 2015 referendum in Poland in memes analyse. In the course of the research such questions will be answered: whether the memes became part of the general overtone of the discourse; whether they presented the main themes of the discourse and how they did this; which elements of the discourse were emphasized in the memes and which were omitted. In the research process the main themes of the discourse were distinguished, which were reflected in the memes.
\end{abstract}

Key words: referendum, Poland, memes

\section{$1 \quad$ INTRODUCTION}

The goal of the article is to analyze memes associated with the nationwide referendum of 6 September 2015. The memes were treated as part of the media discourse and its complement. In the course of the research process, answers were sought to the following questions: whether the memes became part of the general overtone of the discourse; whether they presented the main themes of the discourse and how they did this; which elements of the discourse were emphasized in the memes and which were omitted. In the research process the main themes of the discourse were distinguished, which were reflected in the memes. These cover the reason/reasons for ordering the referendum, referendum questions, the financial costs incurred, and the referendum turnout. The article is divided into several parts which define the main categories: memes and referendum as well as the analysis of selected memes in the context of the distinguished main themes of the discourse on the referendum of 2015.

\section{MEMES}

A meme is "a combination of graphics and text, which is a humorous comment on current events, a presentation of views or emotions". ${ }^{2}$ In a somewhat different sense it denotes "ideas, behaviors, or

1 The article is the result of research project No. 2014/15/B/HS5/01866 funded by the National Science Centre, Poland Mem. [online]. Available at $<\mathrm{https} / / /$ www.semtec.pl/slownik-seo/mem>. [q. 16. 10. 2017].

2 Mem. [online]. Available at $<\mathrm{https} / / / \mathrm{www}$. semtec.pl/slownik-seo/mem $>$. [q. 16.10.2017]. 
the code of conduct under particular circumstances. In a word, everything that culture and civilization have imposed upon over the centuries, inter alia religion: the fact that it is not appropriate to walk naked about town or laugh at a funeral is also a meme. These are patterns of behavior, things associated with a given domain, instilled in us from childhood. We will not get rid of them. They behave like genes - they widely spread from generation to generation of receivers as well as within one generation, they mutate." ${ }^{3}$ A meme is therefore treated as "an evolving unit of cultural information. It is created around recurrent subjects or images that are systematically broadened in reference to the current cultural phenomena, events, behaviors of public figures, etc.." Emphasis is also laid on relationships with Richard Dawkins's meme-ethics of $1976 .{ }^{5}$ In her book The Meme Machine, Susan Blackmore describes the situation when our humming at work spreads virally over the whole office. She gives Blake's Jerusalem as an example and says that the whole inspirational song is a meme. ${ }^{6}$

Literature often uses the concept of the Internet meme. As Wiktor Kołowiecki observes, Internet memes are a new language of the Internet. ${ }^{7}$ By this he means "a digitized unit of information (text, picture film, sound) spread via the Internet that is copied, processed, and published in the Internet in the processed form". "An Internet meme is distinguished by the fact of being an information unit replicated exclusively via the Internet. It should be remembered that replication in this context does not mean digital copying of a given material. Digital replication is perfect, therefore each copy of this type is an original: this process only spreads one item of information in many copies that can differ at most by the quality of compression or be displayed in different colors and shades depending on the picture settings".

\section{REFERENDUM}

The referendum institution is perceived as the most widely used instrument of direct democracy: it means that the eligible voters directly decide through voting on important matters of State life or of a particular territory, which are the subject of the vote. ${ }^{10}$ As a result, "citizens who have political rights are called on to declare themselves in voting on the Constitution, laws, and major problems of State life." ${ }^{11}$ This is how this problem has been regulated at least in Polish legislation.

A nationwide referendum was held on 6 September 2015. The referendum turnout was $7.8 \%$ and was the lowest as compared with the turnouts recorded in all the nationwide referendums held

Czym jest mem? Wywiad z twórcą encyklopedii memów. [online]. Available <http://arturjablonski.com/czym-jestmem-wywiad-tworca-encyklopedii-memow-czesc-1>. [q.10. 03. 2017].

Mem. [online]. Available <https://www.semtec.pl/slownik-seo/mem/>. [q. 12. 04. 2017].

DOWKINS, R. The Selfish Gene. Oxford, New York: Oxford University Press, 1976.

BLACKMORE, S. The Meme Machine. New York: Oxford University Press, 1999.

KOŁOWIECKI, W. Memy internetowe jako nowy język Internetu. [online]. Available <http://www.kulturaihistoria. umcs.lublin.pl/archives/3637>. [q. 18. 05. 2017].

$8 \quad$ Ibid.

9 Ibid. See also: GACKOWSKI, T., BRYLSKA, K., PATERA, M. (ed.): Memy czyli życie społeczne w czasach kultury obrazu. Warszawa: ASPRA-JR, 2017.

10 BANASZAK, B., PREISNER, A. Prawo konstytucyjne. Wprowadzenie. Wrocław: Wydawnictwo Uniwersytetu Wrocławskiego, 1993, p. 139.

11 ZIELIŃSKI, E. Referendum w państwie demokratycznym. In WANIEK, D., STASZEWSKI, M., T. (ed.): Referendum w Polsce współczesnej. Warszawa: ISP PAN, 1995, p. 9. 
in Poland. ${ }^{12}$ The referendum very clearly showed the instrumental use of this institution by various political actors. In other words, the use of the institution expressed the calculations meant to achieve one's own political goals rather than listen to the voice of the people. This is nothing new in Poland. Previously, after 1989, four referendums were held, in which a crucial role was played by the will of those in power. ${ }^{13}$ Both Bronisław Komorowski's proposal to hold a nationwide referendum and Andrzej Duda's rejected proposal to call another nationwide referendum became part of the negative tradition of utilizing this institution by politicians. ${ }^{14}$

\section{THE REASON/REASONS FOR ORDERING THE NATIONWIDE REFERENDUM}

The nationwide referendum of 6 September 2015 was ordered by the decision of the then President Bronisław Komorowski. ${ }^{15}$ The direct cause of the decision to order the referendum was the President's defeat in the first round of the 2015 presidential election. The media discourse widely emphasized the emotional reasons underlying President Komorowski's move. It was pointed out inter alia that the decision was ill-considered, the action was hasty, motivated by the results of the first round of the presidential election unfavorable to President Komorowski, and by the attempt to take over the votes cast for Paweł Kukiz, who supported single-seat constituencies. The presented way of argumentation is reflected in the literature on the subject. ${ }^{16}$

In general, people did not like Bronisław Komorowski's ordering the referendum for purely electoral reasons to take over the votes cast for Paweł Kukiz, and thereby increase his (President's) chances of success in the second round of elections, which he lost anyway. The same motivation was behind the intention of the now incumbent President Andrzej Duda, who wanted to order another referendum. The Internet users correctly and explicitly identified President B. Komorowski's reason: For fear that he would lose his position he blew a 100 million zloty overnight (meme 1).

12 Obwieszczenie Państwowej Komisji Wyborczej z dnia 23 listopada 2015 r. o skorygowanych wynikach głosowania i wyniku referendum ogólnokrajowego przeprowadzonego w dniu 6 września 2015 r. In Dziennik Ustaw, 2015, poz. 2035.

13 MARCZEWSKA-RYTKO, M. Direct Democracy At the National Level in Poland. The Case of Referendum. In Annales Universitatis Mariae Curie-Skłodowska Sectio K: Politologia Vol. XX (2013), p. 103 - 115; MARCZEWSKA-RYTKO, M. Direct Democracy in Poland. In MARCZEWSKA-RYTKO, Maria (ed.): Handbook of Direct Democracy in Central and Eastern Europe after 1989. Opladen, Berlin, Toronto: Barbara Budrich Publischers, 2018, p. 203 - 223.

14 MARCZEWSKA-RYTKO, M. Krytyczna analiza dyskursu "Gazety Wyborczej" na przykładzie referendum ogólnokrajowego w Polsce w 2015 roku. In GACKOWSKI, T., BRYLSKA, K. (ed.): Gry w komunikacji. Warszawa: Oficyna Wydawnicza ASPRA-JR, 2016, p. 75 - 95.

15 Postanowienie Prezydenta Rzeczypospolitej Polskiej z dnia 17 czerwca 2015 r. o zarządzeniu ogólnokrajowego referendum. In Dziennik Ustaw, 2015, poz. 852.

16 MARCZEWSKA-RYTKO, M. A Critical Analysis of the Media Discourse in Daily Newspaper Gazeta Wyborcza. Based on the Example of the Nationwide Referendum in Poland in 2015. In Politics, Culture and Socialization. Vol. 7, No. 1 - 2 (2016), p. $42-56$. 


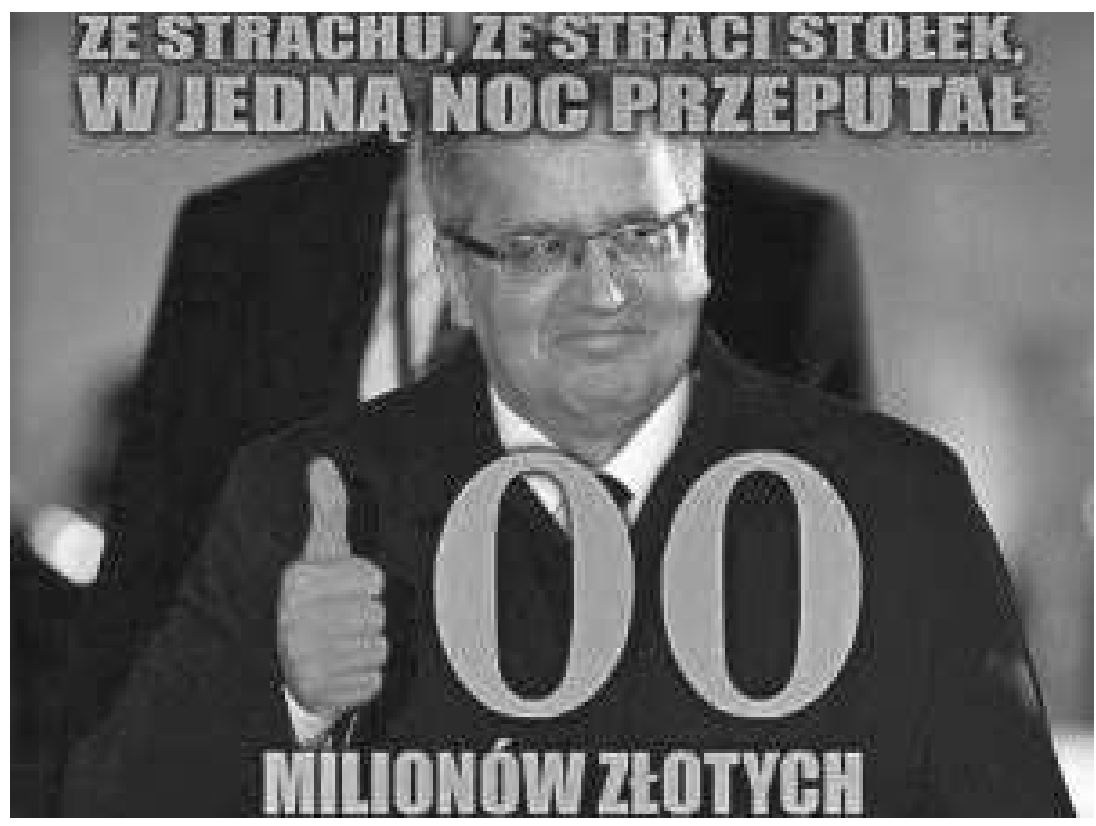

Meme 1: For fear that he would lose his position he blew a 100 million zloty overnight. ${ }^{17}$

In other words, no matter at what cost, what mattered was to achieve the set objective and win the election. The nationwide referendum was thus treated instrumentally as a way of maintaining power.

\section{REFERENDUM QUESTIONS}

President Bronisław Komorowski proposed calling a nationwide referendum, in which he asked the following questions: Are you in favor of introducing single-seat constituencies in the elections to the Sejm of the Republic of Poland? Are you for maintaining the existing way of funding political parties from the State budget? Are you for introducing the general principle of resolving doubts about the interpretation of tax law provisions in favor of the tax payer? ${ }^{18}$

In the media discourse, the sense and constitutionality of the referendum questions was contested. ${ }^{19}$ It was stressed that a referendum is not the best solution in tax cases. The prevalent belief was that there is no reasonable alternative to funding political parties from the State budget. It was pointed out that, firstly, the introduction of funding of parties in 2001 civilized the Polish political system; secondly, funding of parties from the State budget is a European norm, thirdly, that the problem was not the way of funding political parties but the supervision over spending this money.

President A. Duda's motion to call a referendum contained three questions: Are you for maintaining the existing system of the operation of the State Forest Holding - State Forests? Are

17 Mem in the author's collections.

18 Postanowienie Prezydenta Rzeczypospolitej Polskiej z dnia 17 czerwca 2015 r. o zarządzeniu poprzednich. ogólnokrajowego referendum...

19 MARCZEWSKA-RYTKO, M. A Critical Analysis of the Media Discourse in daily newspaper Gazeta Wyborcza, op. cit. 
you for the abolishment of the school obligation for six year olds and re-introduction of the school obligation at the age of seven? Are you for lowering the retirement age and combining the pension rights with the job seniority $?^{20}$

In the discourse, there were suggestions that the list of questions should be expanded: Do you want taxes to be lowered? Do you want the State to cover a portion of the costs of your holidays in Ibiza? Do you want to earn more than five thousand zloty net? ${ }^{21}$ There were also suggestions of adding questions about the euro, about religion at school, about the use of the in vitro method and NaProTechnology, about funding the Catholic Church, and whether everyone should have at least an 80-square-meter apartment, or whether to abolish so-called junk (i.e. civil law) job contracts?

The proposals to expand the list of referendum questions were reflected in many memes. One of these questions was: Do you support the idea of Poland from sea to sea? (Meme 2). In other words, are you are in favor of Poland's new borders defined by the Black Sea and the Baltic Sea?

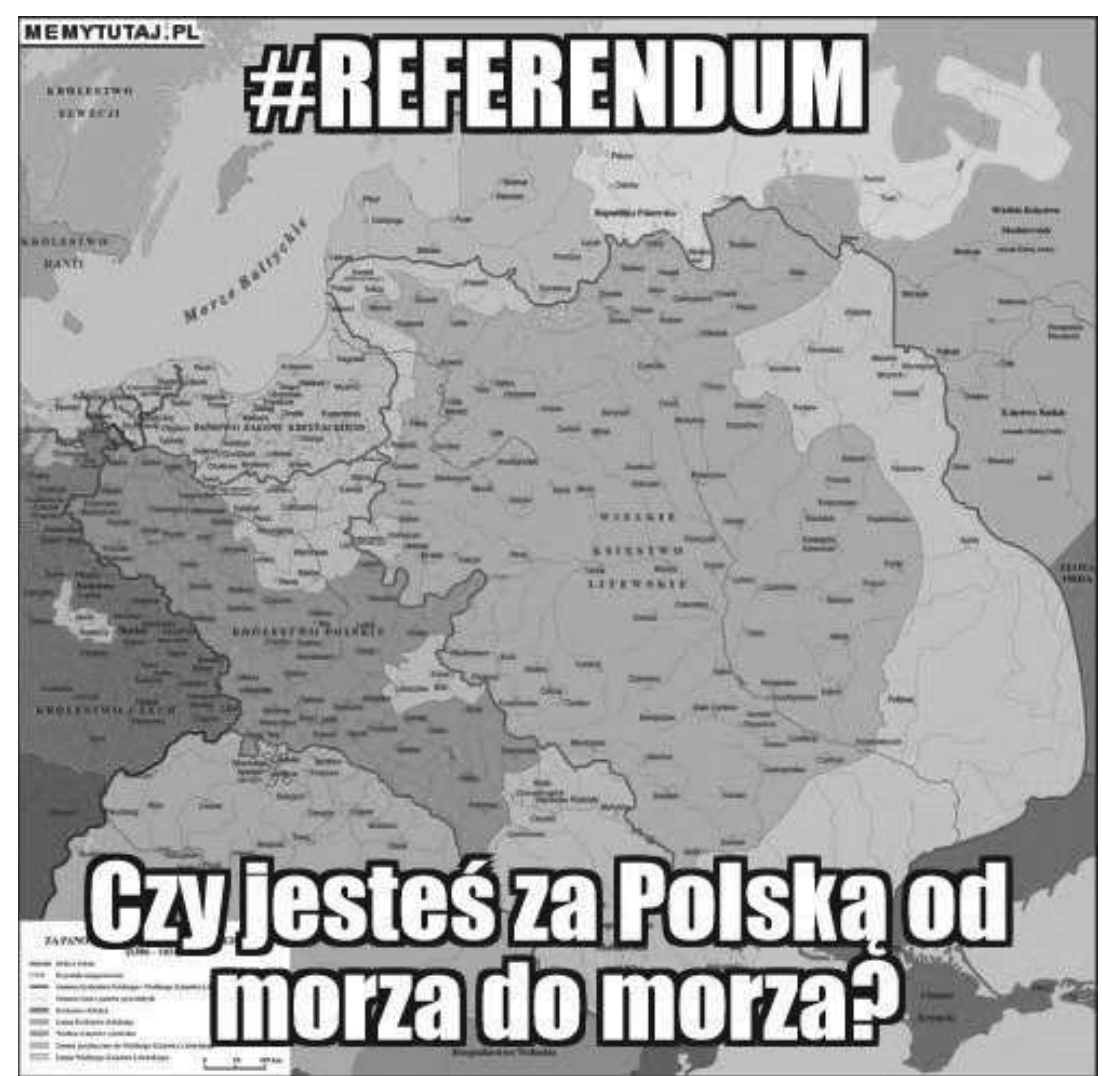

Meme 2: Do you support the idea of Poland from sea to sea? ${ }^{22}$

Another example of questions asked in the memes referred to the immigration crisis in Europe. In 2015 , four times as many illegal aliens arrived in the territory of the European Union as in the previ-

20 Ibid.

21 Ibid.

22 Czy jesteś za Polską od morza do morza. [online]. Available at <http://memytutaj.pl/referendum-czy-jestes-za-polskaod-morza-do-morza-178237>. [q. 11. 10. 2017]. 
ous years. As Anita Adamczyk observes, "the growing number of applicants for a refugee status in the EU countries was observable already in 2012. By the end of 2013, however, this increase had not been as spectacular as at the end of 2014 and into 2015 . Then the number of applicants rose from 627,780 to $1,255,640 " .23$ The attitudes of EU societies, including the Polish society, towards immigrants, the stance of the European Union and the policy of the Polish authorizes in this area became a significant element of the media discourse. Katarzyna Andrejuk stresses that "studying the attitudes towards immigrants is becoming particularly important in the context of intensified immigration to Poland (as well as to other European countries) and in connection with the refugee crisis in the European Union. This issue embraces both the questions of perceiving immigrant communities living in a given EU country and the views and expectations concerning the question of the policy of multiculturalism, for example the obligation to take in foreigners (including refugees)" ${ }^{24}$ In this context, the memes also contained the question: Are you for taking in immigrants to Poland? (meme 3).

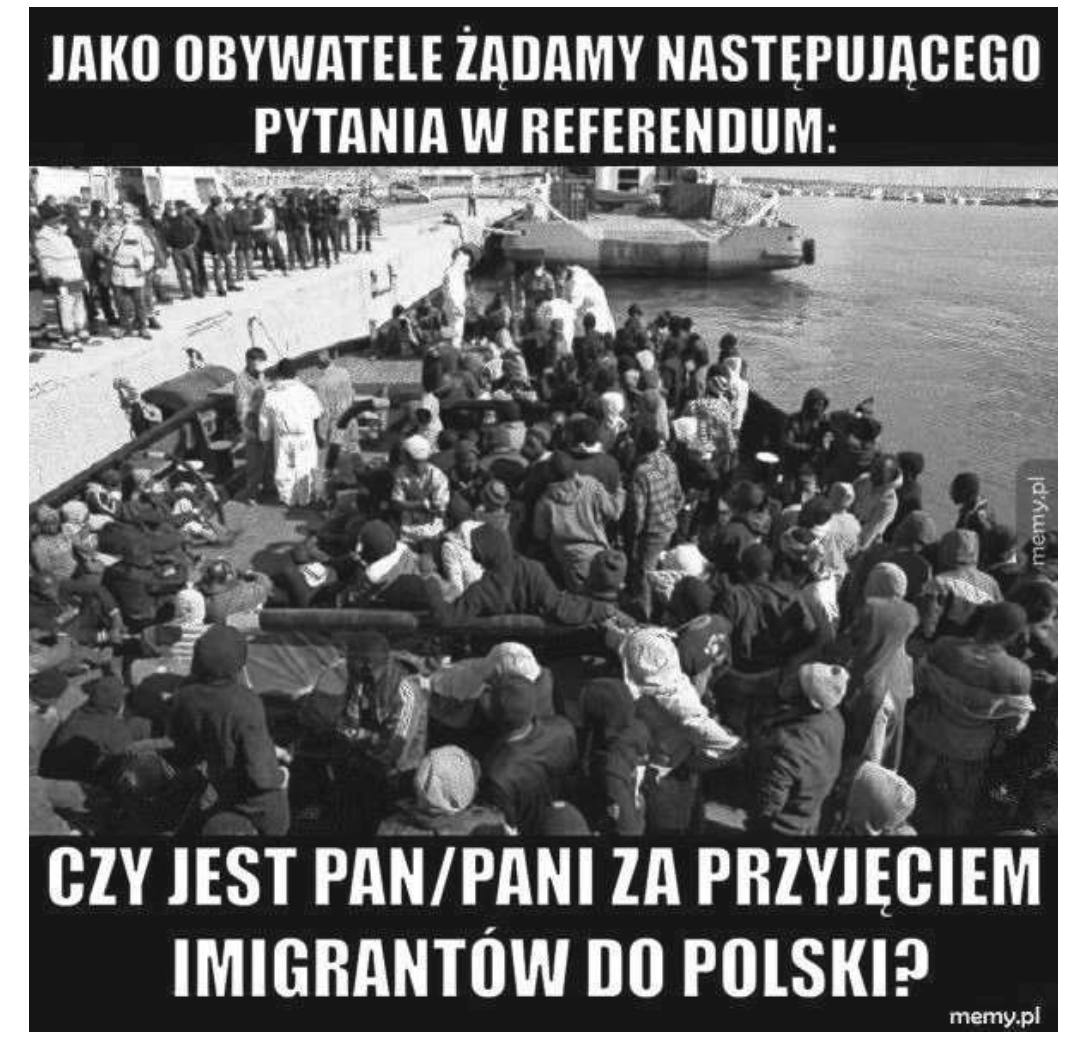

Meme 3: Are you for taking in immigrants to Poland? ${ }^{25}$

23 ADAMCZYK, A. Kryzys migracyjny w Europie a polska polityka imigracyjna. In Studia Migracyjne - Przegląd Polonijny. No. 1 (2017), p. 308.

24 ANDREJUK, K. Postawy wobec imigrantów w świetle wyników Europejskiego Sondażu Społecznego 2014 - 2015. Polska na tle Europy. [online]. Available at <http://www.ifispan.pl/wp-content/uploads/2015/12/Postawy-wobecimigrant\%C3\%B3w-w-\%C5\%9Bwietle-wynik\%C3\%B3w-Europejskiego-Sonda\%C5\%BCu-Spo\%C5\%82ecznego-20142015.-Polska-na-tle-Europy.pdf>. [q. 10. 04. 2017].

25 Jako obywatele żądamy następującego pytania w referendum. [online]. Available at <http://bibsy.pl/owq0jozG/jakoobywatele-zadamy-nastepujacego-pytania-w-referendum-czy-jest-panpani-za-przyjeciem-imigrantow-do-polski $>$. [q. 13. 10. 2017]. 
One more example of a referendum question included in the memes is Bronisław Komorowski's reflection, who says: Damn, I could have also called a referendum on TV license (meme 4).

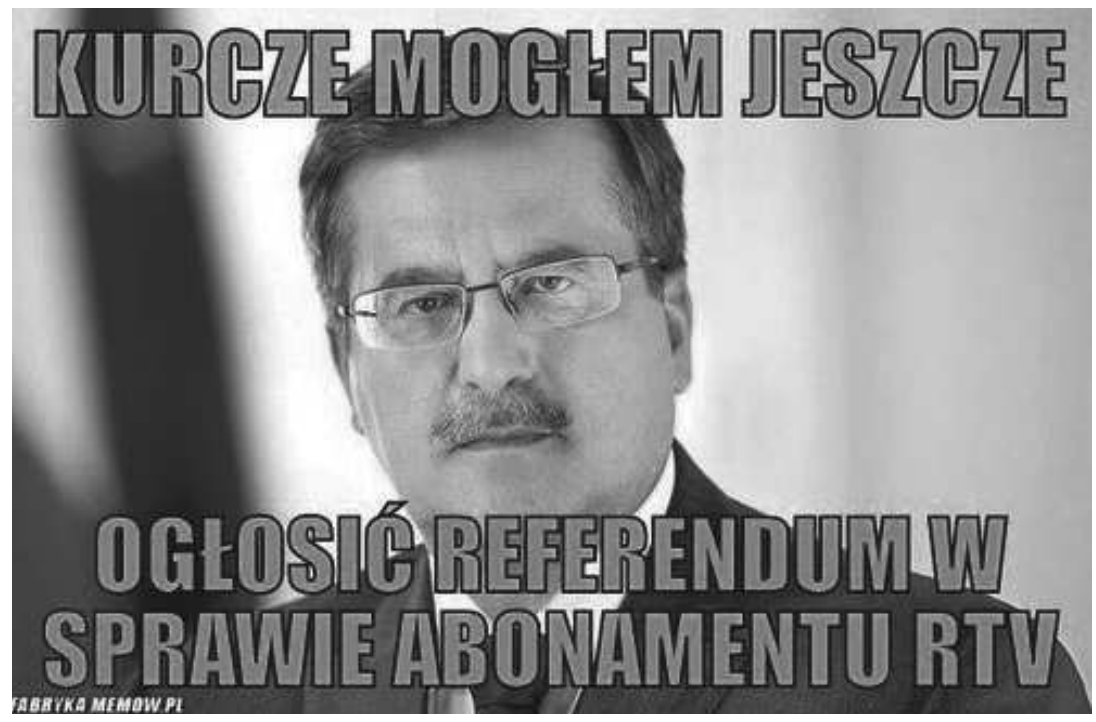

Meme 4: Damn, I could have also called a referendum on TV license. ${ }^{26}$

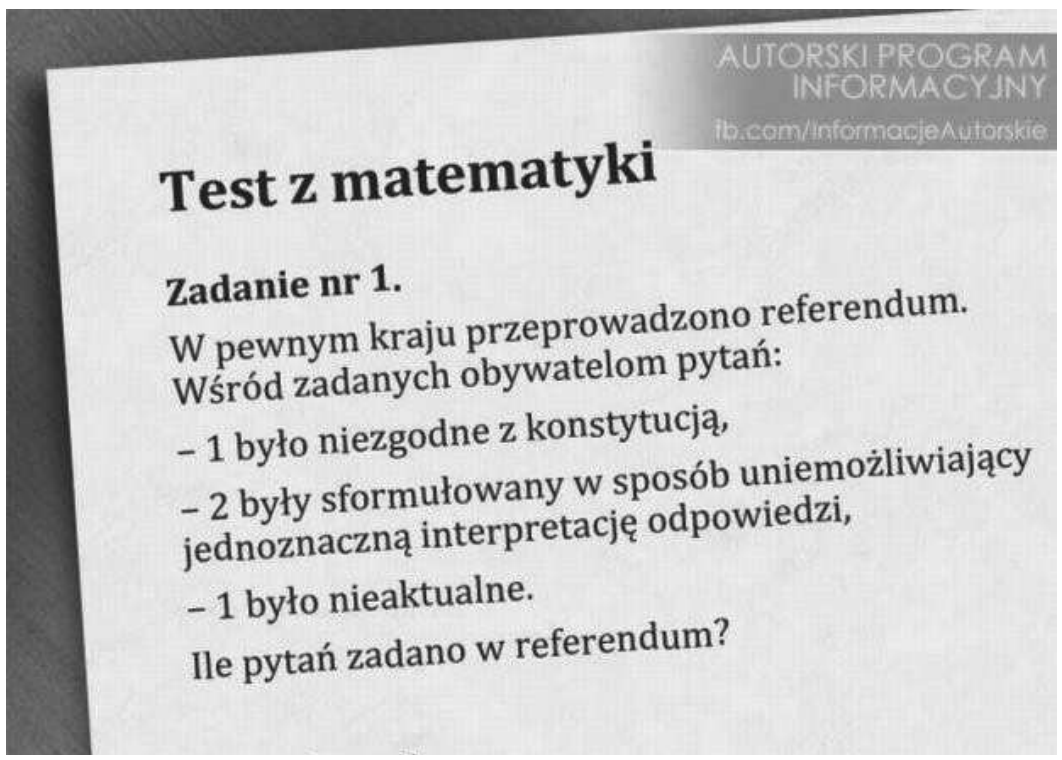

Meme 5: How many questions were asked in the referendum if the first was unconstitutional; in the second, an unambiguous interpretation was impossible, and the third one was no longer topical. ${ }^{27}$

26 Kurcze mogłem jeszcze. [online]. Available at <https://fabrykamemow.pl/uimages/services/fabrykamemow/i18n/pl_ PL/201505/1432285132_by_anonymous_500.jpg?1432285132>. [q. 4. 10. 2017].

27 Referendum poniosło klęskę. [online]. Available at <http://buzz.gazeta.pl/buzz/56,156947,18721774,referendum-ponioslo-kleske-tak-na-to-zapatruja-sie-uzytkownicy.html>. [q. 19. 10. 2017]. 
In Poland, the TV/radio license fee levied by the Act of 21 April 2005 on license fees is a payment meant to enable public TV and Radio to carry out their mission. The amount of the TV/radio license fee is set by the National Broadcasting Council (KRRiT), and the institution responsible for collecting is the Polish Post (Poczta Polska). ${ }^{28}$ The Civic Platform (Platforma Obywatelska), the party from which President B. Komorowski came, supported its reduction, and the next step would be to abolish the fee. Prime Minister Donald Tusk termed it "archaic" in 2008 called it an "imposed charge". The question of TV/Radio license fee has always provoked great controversy in Poland. ${ }^{29}$

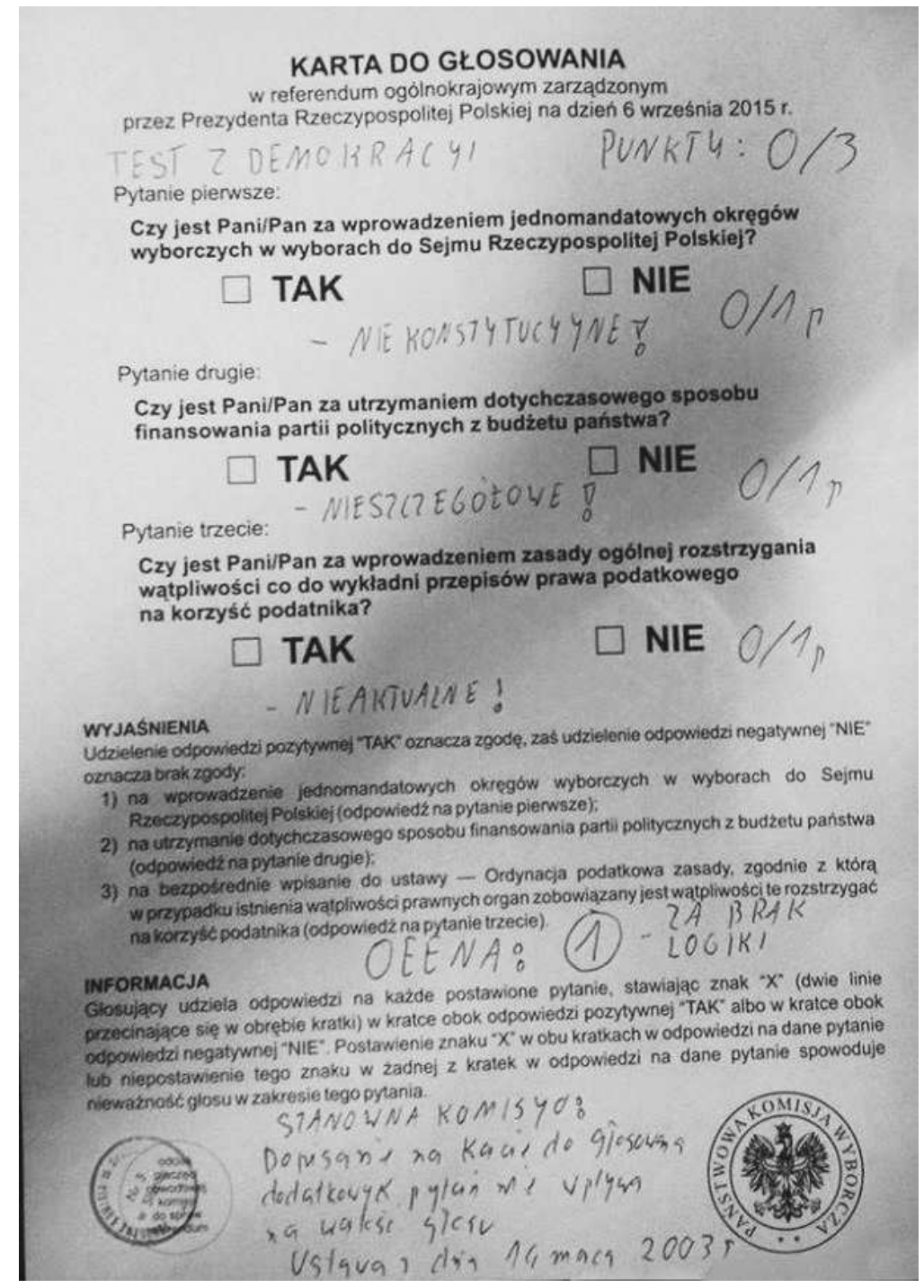

Meme 6: A ballot card. ${ }^{30}$

28 Ustawa z dnia 21 kwietnia 2005 r. o opłatach abonamentowych. In Dziennik Ustaw, 2014 r. poz. 1204.

29 pap, ss: Tusk: abonament rtv to haracz. In Wprost, 29. 04. 2008.

30 Lawina memów po wczorajszym referendum. [online]. Available at <https://joemonster.org/art/33380>. [q. 18. 10. 2017]. 
Apart from the proposals for new questions, the memes contained the analysis of the questions asked in the referendum. One such meme contains an example of a mathematics test. The task consists in a logical puzzle containing the question: How many questions were asked in the referendum if the first was unconstitutional; in the second, an unambiguous interpretation was impossible, and the third one was no longer topical (Meme 5).

In another meme, the basis for a test in democracy was a ballot card (meme 6).

It had Grade 1 (Fail) given for the lack of logic (meme 6) because Question One was assessed as unconstitutional, Question Two as non-specific, and Question Three as not topical (irrelevant).

\section{THE COSTS OF THE REFERENDUM}

The total cost of holding the referendum amounted to 84 million zloty. Questions were asked in the media discourse about funding, the waste of public money being pointed out first of all.

The memes referred inter alia to Lech Wałęsa and his hundred million old zloty (meme 7).

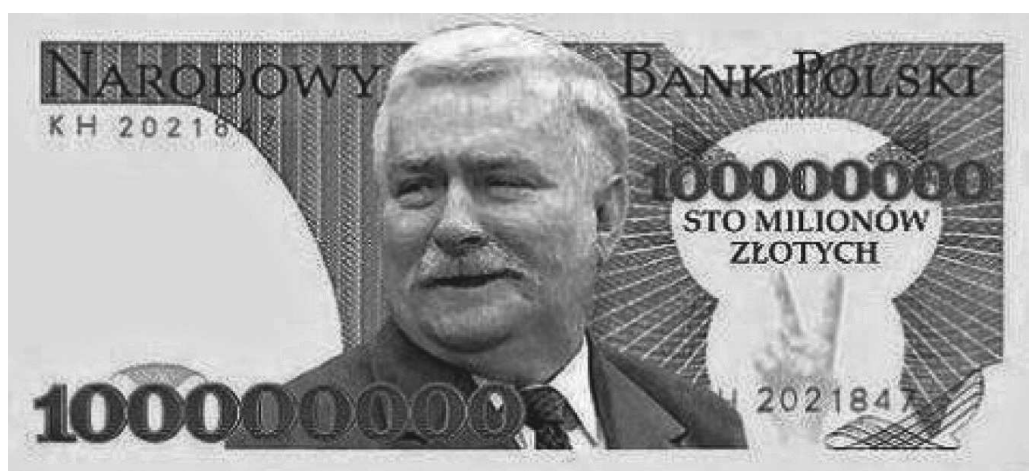

Meme 7: Lech Wałęsa and his hundred million old zloty. ${ }^{31}$

Lech Wałęsa and Tadeusz Mazowiecki ran for the office of the Head of State in the presidential election of 1990. During his presidential campaign L. Wałęsa made many promises while seeking election. One of them was the promise to allot one hundred million old zloty to each citizen, the average wages not exceeding one million zloty at that time. The money would come from the privatization of State-owned enterprises. The promise of one hundred million old zloty for each citizen remained a mere election promise, and was never fulfilled.

The memes also referred to Madonna's concert at the National Stadium in Warsaw in 2012. ${ }^{32}$ Joanna Mucha of the Civic Platform, the then Minister of Sport, says: Waste of money. I could have organized twenty Madonna concerts for that amount (meme 8).

31 Frekwencyjny niewypał referendum. [online]. Available at <http://www.newsweek.pl/polska/porazka-referendummemy-,galeria,370051,1,1,6.html>. [q. 16. 10. 2017].

32 MALINOWSKI, P. Ogromne straty po koncercie Madonny w Warszawie. In Rzeczpospolita, 08. 05. 2013. 


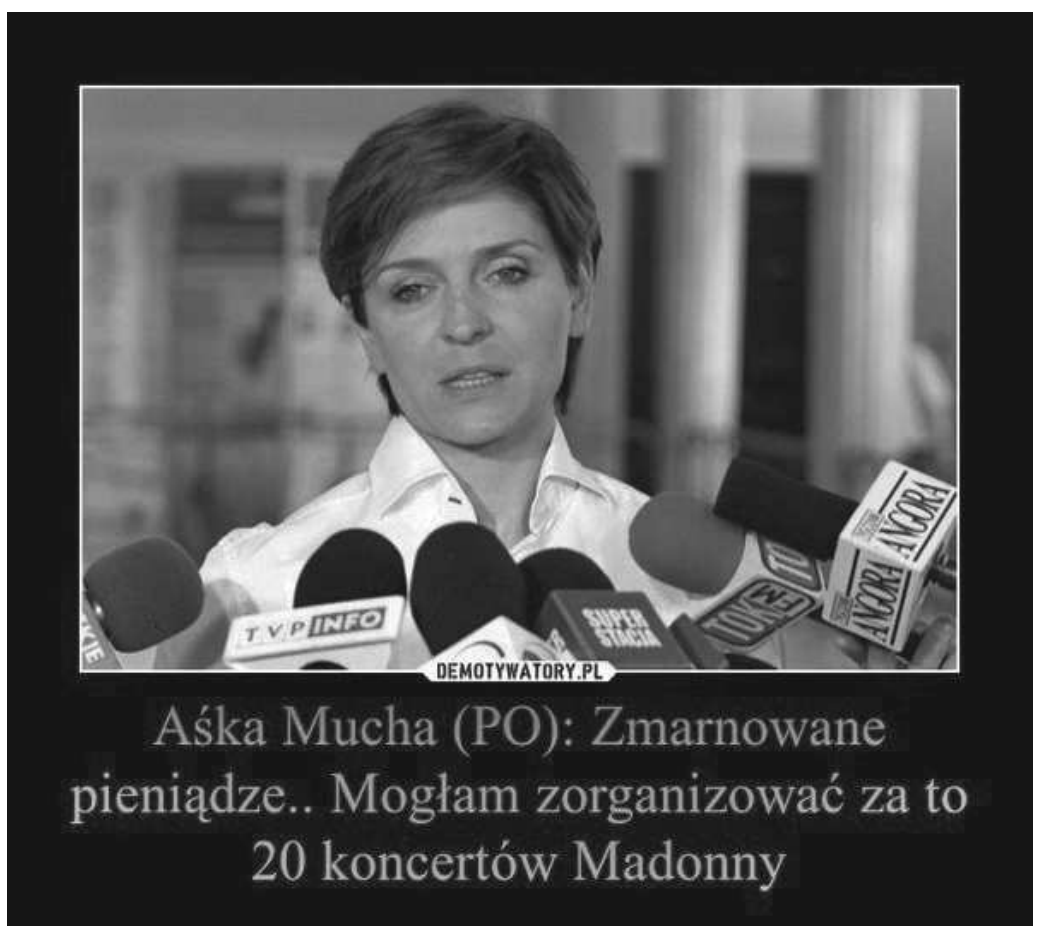

Meme 8: Waste of money. I could have organized twenty Madonna concerts for that amount. ${ }^{33}$

Madonna's concert took place on 1 August 2012 and was the first non-sporting event organized at the National Stadium after Euro 2012. The concert cost five million zloty. It provoked many controversies, mainly because of the date (it was held on the anniversary of the outbreak of the Warsaw Uprising) and the financial losses involved. Attendance at the concert was far lower than the organizers had expected. Nor were any sponsors found. Ultimately, the financial losses were covered by the Ministry of Sport. ${ }^{34}$

The memes also emphasized the carefree spending of public money, mismanagement, and "throwing money down the drain" (memes 9 and 10).

33 Zmarnowane pieniądze [online]. Available at <https://demotywatory.pl/4546075/Aska-Mucha-(PO)--Zmarnowanepieniadze-Moglam-zorganizowac-za-to-20-koncertow-Madonny>. [q. 14. 10. 2017].

34 Umorzono śledztwo w sprawie koncertu Madonny na Stadionie Narodowym. [online]. Available at <http://www.rmf24. pl/fakty/polska/news-umorzono-sledztwo-ws-koncertu-madonny-na-stadionie-narodowym, nId,1451341\#utm_source=paste $\&$ utm_medium=paste $\&$ utm_campaign $=$ firefox $>$. [q. 19. 05. 2017]. 


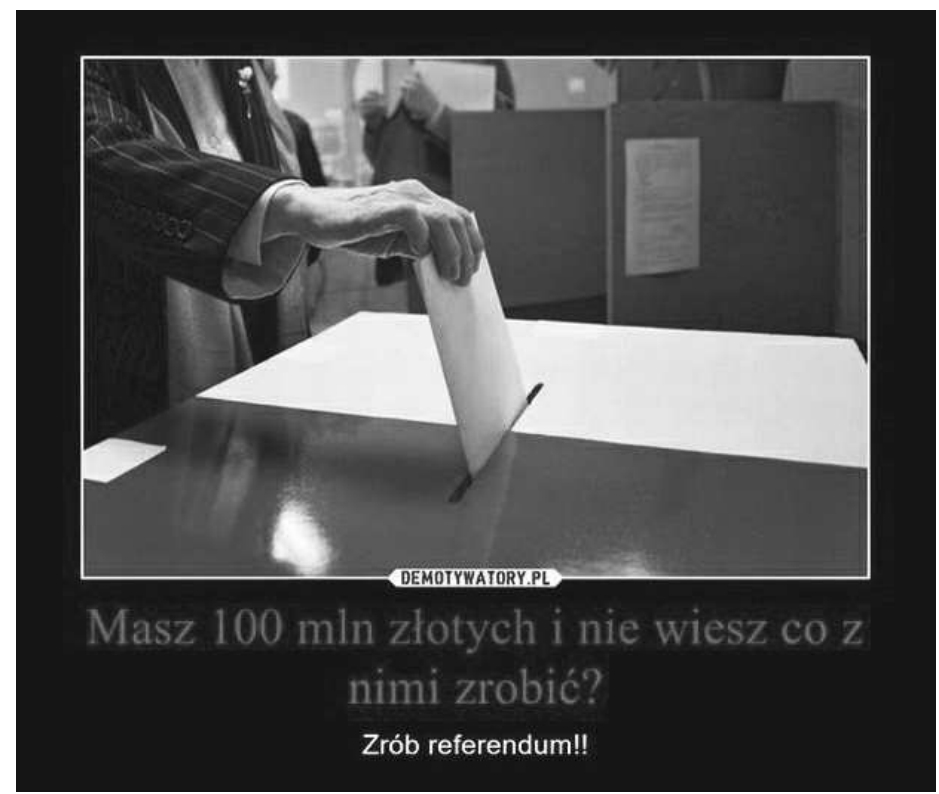

Meme 9: You've got 100 million and don't know what to do with it? Hold a referendum. ${ }^{35}$

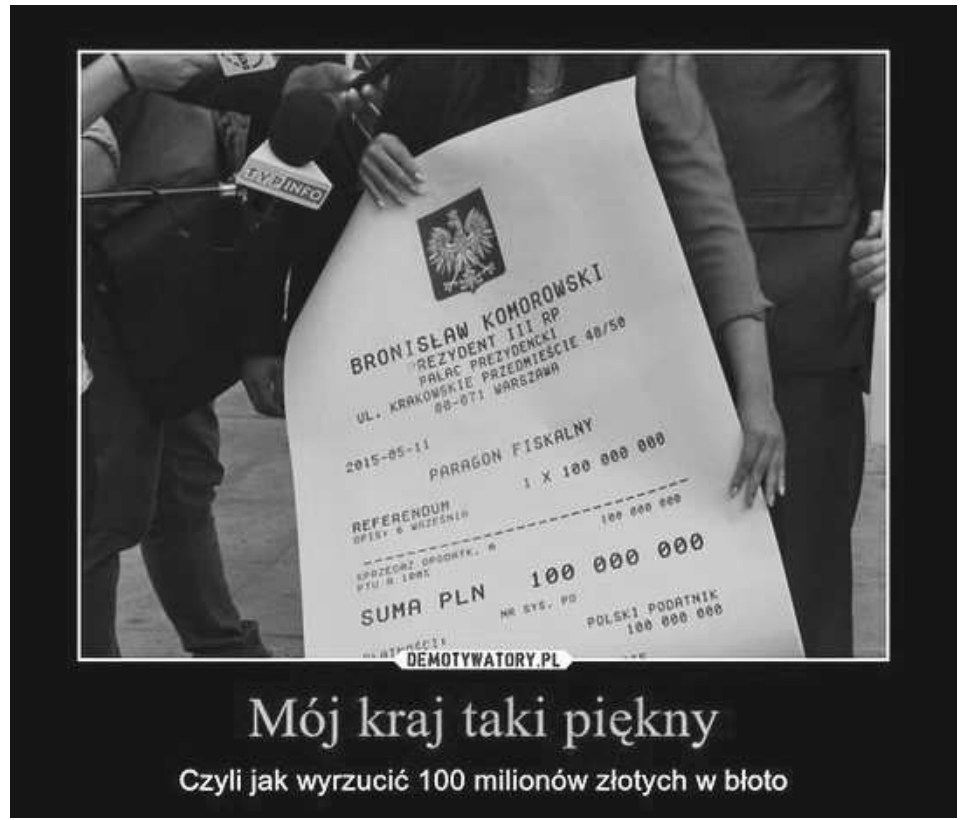

Meme 10: A cash-register receipt made out for the President with the words: My country is so beautiful, or how to throw a hundred million zloty down the drain. ${ }^{36}$

35 Referendum. Najlepsze memy. [online]. Available at <https://www.wprost.pl/galeria/7231/5/Referendum-Najlepszememy.html>. [q. 15. 10. 2017].

36 Referendum. Najlepsze memy. [online]. Available at <https://www.wprost.pl/galeria/7231/11/Referendum-Najlepszememy.html>. [q. 10. 10. 2017]. 


\section{REFERENDUM TURNOUT}

The level of turnout in the 2015 referendum became the subject of both in-depth studies and jokes and derision in the media discourse, including the presented memes. One of the memes showed B. Komorowski leaning over the microscope. Below is the caption: Bronisław Komorowski is admiring the turnout in the referendum (meme 11).

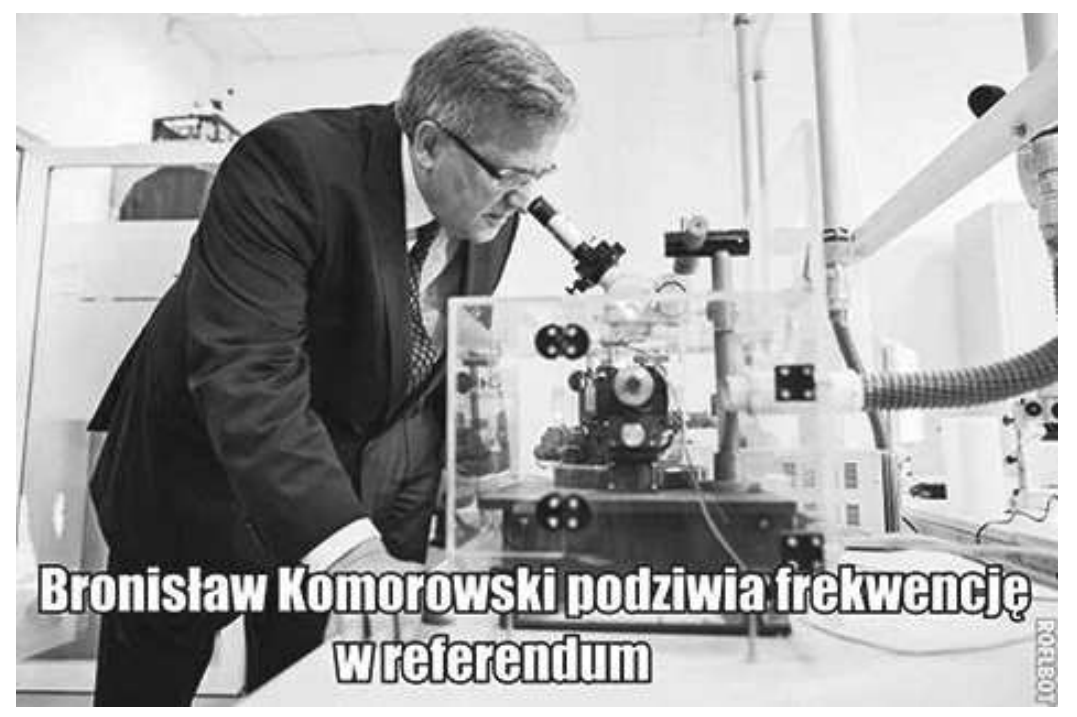

Meme 11: Bronislaw Komorowski is admiring the turnout in the referendum. ${ }^{37}$

Another meme refers to the Paweł Kukiz, the main advocate of the idea of single-seat constituencies in the election campaign. Surprised by the turnout, Kukiz asks: What do you mean? They don't want single-seat constituencies? (meme 12).

Some of the memes referred to associations with manipulations with votes. In one meme Jarosław Kaczyński says: The referendum was rigged! Just kidding (meme 13).

In this case references were also made to the problems that arose in connection with holding local government elections. The first round of the election took place on 16 November 2014 and the second round on 30 November. When the votes were counted, the computer system failed and it was necessary to wait for the results much longer than in the case of earlier elections. This prompted opinions in the public debate that the election had been rigged.

A comparison was also made with the scores of the Polish football team (meme 14). It was pointed out that the result of the match was higher than the referendum turnout.

37 Frekwencyjny niewypał referendum. [online]. Available at <http://www.newsweek.pl/polska/porazka-referendum-memy-,galeria,370051,1,1,4.html>. [q. 10. 10. 2017]. 


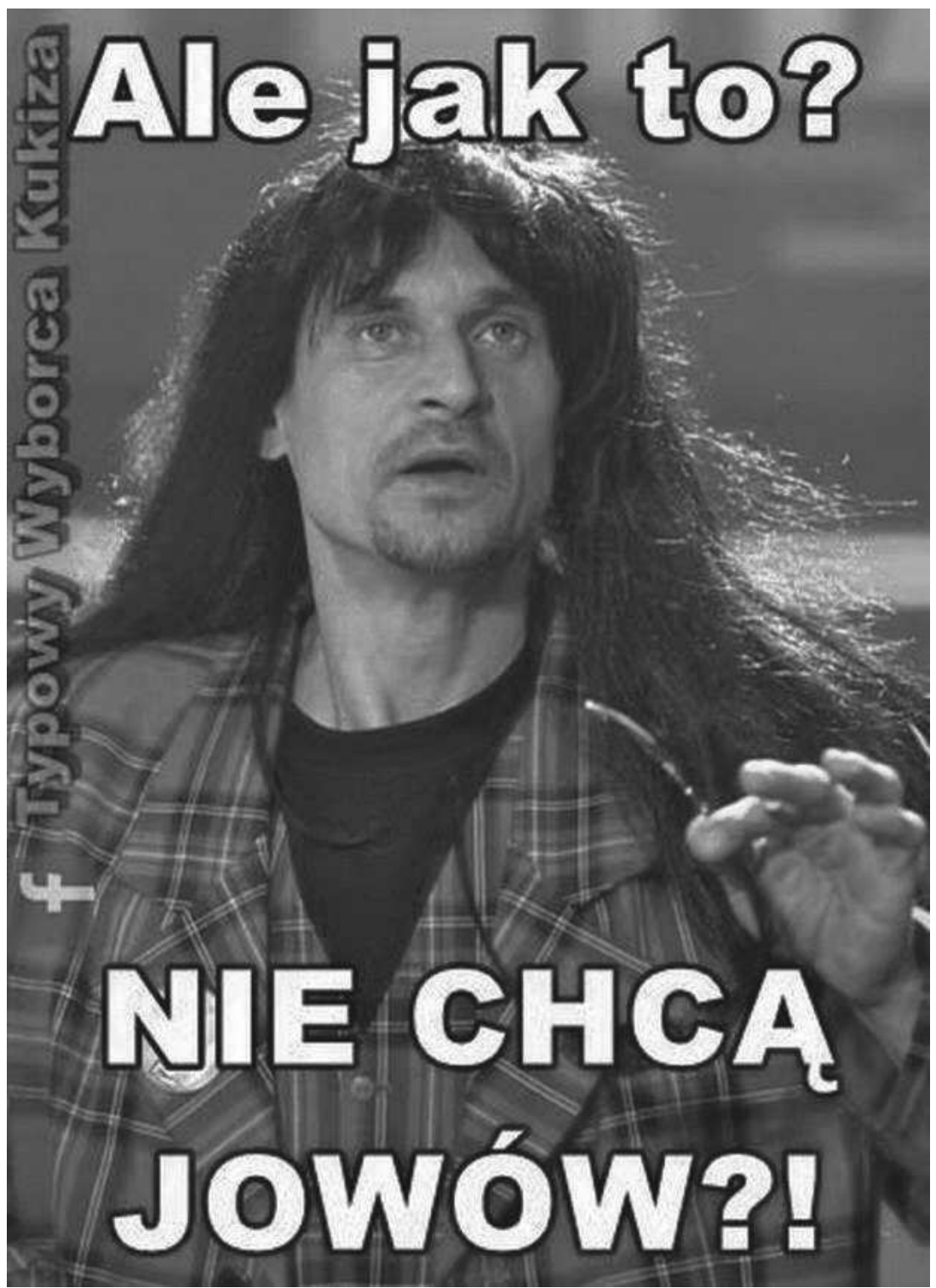

Meme 12: What do you mean? They don't want single-seat constituencies? ${ }^{38}$

38 Referendum. Najlepsze memy. [online]. Available at <https://www.wprost.pl/galeria/7231/Referendum-Najlepszememy.html>. [q. 16. 10. 2017]. 


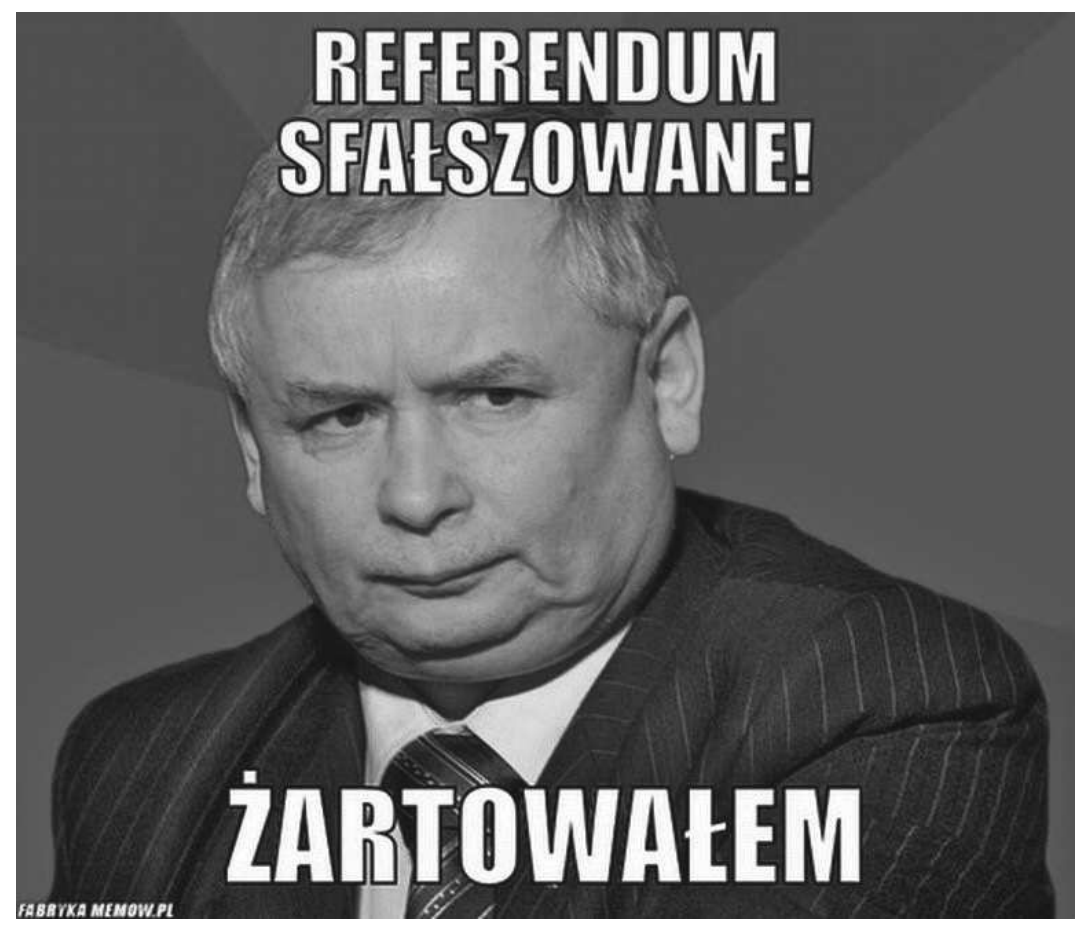

Meme 13: The referendum was rigged! Just kidding. ${ }^{39}$

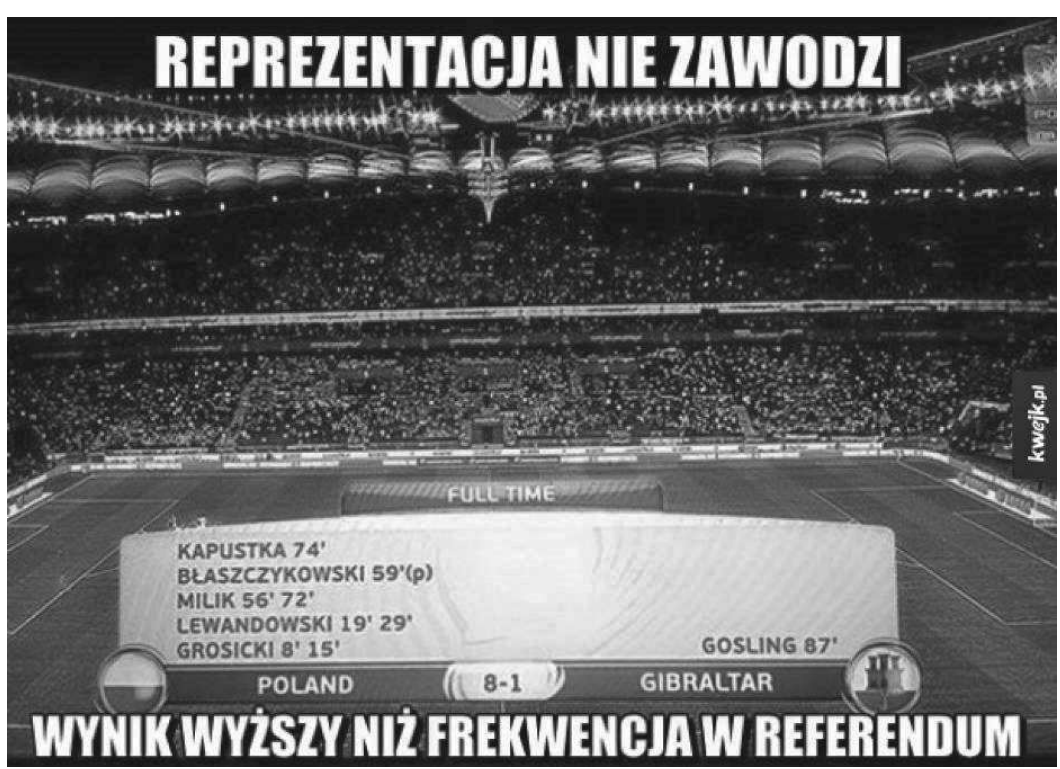

Meme 14: The scores of the Polish football team. ${ }^{40}$

39 Referendum poniosło klęskę. [online]. Available at <http://buzz.gazeta.pl/buzz/56,156947,18721774,referendumponioslo-kleske-tak-na-to-zapatruja-sie-uzytkownicy.html>. [q. 10. 10. 2017].

40 Reprezentacja nie zawodzi. [online]. Available at $<$ https://demotywatory.pl/4546584>. [q. 16. 10. 2017]. 
In the media discourse, reflective memes also appeared. One of them is a meme showing a child saying between his teeth: We don't want a referendum. We want a playground (meme 15).

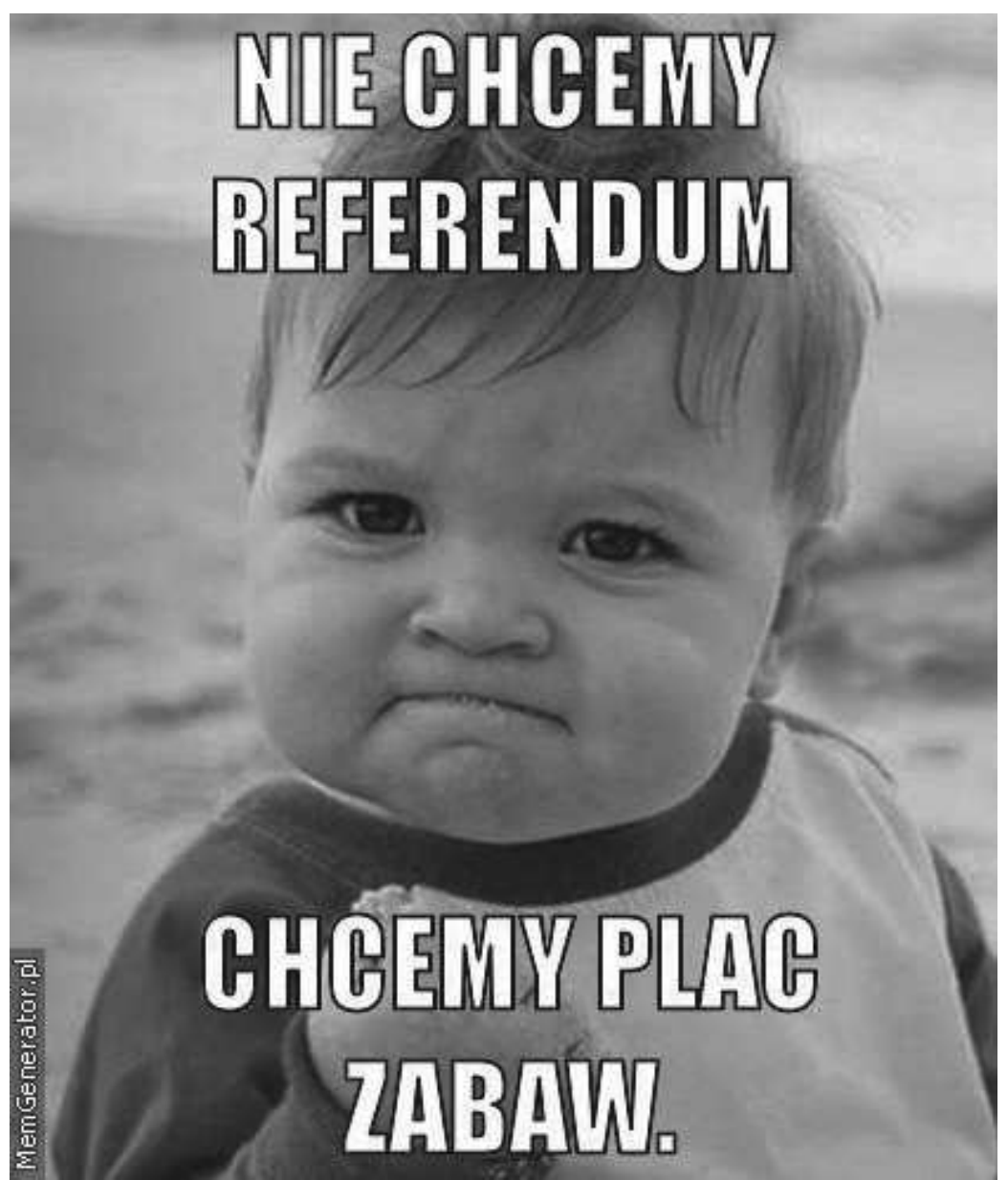

Meme 15: We don't want a referendum. We want a playground. ${ }^{41}$

The voters are presented here as children. What needs to be emphasized is the fact that in the media discourse this theme appeared many times: the citizens are not capable of directly participating in the decision-making process.

\section{CONCLUSION}

The conducted analysis allows several conclusions. Firstly, memes are a significant part in the media discourse covering individual stages of the conduct of the nationwide referendum in 2015. Secondly,

41 Nie chcemy referendum. [online]. Available at <http://pl.memgenerator.pl/mem/nie-chcemy-referendum-chcemy-placzabaw-pl-ffffff>. [q. 14. 10. 2017]. 
in the course of the investigation it turned out that the specified main themes of discourse (embracing the reason/reasons for ordering the referendum, referendum questions, the financial costs incurred, and the referendum turnout) were fully reflected in the memes. Thirdly, the conducted research confirmed that the memes became part of the general undertone of the discourse unfavorable to those in power and the referendum institution itself. It should however be emphasized that some of them also highlight the unfavorable image of the voter. It should also be observed that the memes illustrated the main themes of the media discourse, interpreting them in a sarcastic, jocular but also reflective manner that became embedded in one's memory. In general, all the most important elements of the media discourse were manifested in the memes.

\section{Bibliography:}

ADAMCZYK, A. Kryzys migracyjny w Europie a polska polityka imigracyjna. In Studia Migracyjne - Przegląd Polonijny. No. 1 (2017).

ANDREJUK, K. Postawy wobec imigrantów w świetle wyników Europejskiego Sondażu Społecznego 2014 - 2015. Polska na tle Europy. [online]. Available at http://www.ifispan.pl/wp-content/uploads/2015/12/Postawy-wobecimigrant\%C3\%B3w-w-\%C5\%9Bwietle-wynik\%C3\%B3w-Europejskiego-Sonda\%C5\%BCu-Spo\%C5\%82ecznego2014-2015.-Polska-na-tle-Europy.pdf>. [q. 10. 04. 2017].

BANASZAK, B., PREISNER, A. Prawo konstytucyjne. Wprowadzenie. Wrocław: Wydawnictwo Uniwersytetu Wrocławskiego, 1993.

BLACKMORE, S. The Meme Machine. New York: Oxford University Press, 1999.

Czy jesteś za Polską od morza do morza. [online]. Available at <http://memytutaj.pl/referendum-czy-jestes-za-polskaod-morza-do-morza-178237>. [q. 11. 10. 2017].

Czym jest mem? Wywiad z twórcą encyklopedii memów. [online]. Available <http://arturjablonski.com/czym-jestmem-wywiad-tworca-encyklopedii-memow-czesc-1>. [q.10. 03. 2017].

DOWKINS, R. The Selfish Gene. Oxford, New York: Oxford University Press, 1976.

Frekwencyjny niewypał referendum. [online]. Available at <http://www.newsweek.pl/polska/porazka-referendummemy-,galeria,370051,1,1,6.html>. [q. 16. 10. 2017].

Frekwencyjny niewypał referendum. [online]. Available at $<\mathrm{http} / /$ www.newsweek.pl/polska/porazka-referendummemy-,galeria,370051,1,1,4.html>. [q. 10. 10. 2017].

GACKOWSKI, T., BRYLSKA, K., PATERA, M. (ed.): Memy czyli życie społeczne w czasach kultury obrazu. Warszawa: ASPRA-JR, 2017.

Jako obywatele żądamy następującego pytania w referendum. [online]. Available at <http://bibsy.pl/owq0jozG/ jako-obywatele-zadamy-nastepujacego-pytania-w-referendum-czy-jest-panpani-za-przyjeciem-imigrantow-dopolski>. [q. 13. 10. 2017].

KOŁOWIECKI, W. Memy internetowe jako nowy język Internetu. [online]. Available <http://www.kulturaihistoria. umcs.lublin.pl/archives/3637>. [q. 18. 05. 2017].

Kurcze mogłem jeszcze. [online]. Available at <https:/fabrykamemow.pl/uimages/services/fabrykamemow/i18n/ pl_PL/201505/1432285132_by_anonymous_500.jpg?1432285132>. [q. 4. 10. 2017].

Lawina memów po wczorajszym referendum. [online]. Available at $<$ https://joemonster.org/art/33380>. [q. 18. 10. 2017].

MALINOWSKI, P. Ogromne straty po koncercie Madonny w Warszawie. In Rzeczpospolita, 08. 05. 2013.

MARCZEWSKA-RYTKO, M. A Critical Analysis of the Media Discourse in Daily Newspaper Gazeta Wyborcza. Based on the Example of the Nationwide Referendum in Poland in 2015. In Politics, Culture and Socialization. Vol. 7, No. 1 - 2 (2016), p. $42-56$.

MARCZEWSKA-RYTKO, M. Direct Democracy At the National Level in Poland. The Case of Referendum. In Annales Universitatis Mariae Curie-Skłodowska Sectio K: Politologia. Vol. XX (2013), p. 103 - 115; MARCZEWS- 
KA-RYTKO, M. Direct Democracy in Poland. In MARCZEWSKA-RYTKO, Maria (ed.): Handbook of Direct Democracy in Central and Eastern Europe after 1989. Opladen, Berlin, Toronto: Barbara Budrich Publischers, 2018, p. $203-223$.

MARCZEWSKA-RYTKO, M. Krytyczna analiza dyskursu “Gazety Wyborczej” na przykładzie referendum ogólnokrajowego w Polsce w 2015 roku. In GACKOWSKI, T., BRYLSKA, K. (ed.): Gry w komunikacji. Warszawa: Oficyna Wydawnicza ASPRA-JR, 2016, p. 75 - 95.

Mem. [online]. Available <https://www.semtec.pl/slownik-seo/mem/>. [q. 12. 04. 2017].

Mem. [online]. Available at <https://www.semtec.pl/slownik-seo/mem>. [q. 16. 10. 2017].

Nie chcemy referendum. [online]. Available at <http://pl.memgenerator.pl/mem/nie-chcemy-referendum-chcemyplac-zabaw-pl-ffffff>. [q. 14. 10. 2017].

Obwieszczenie Państwowej Komisji Wyborczej z dnia 23 listopada 2015 r. o skorygowanych wynikach głosowania i wyniku referendum ogólnokrajowego przeprowadzonego w dniu 6 września 2015 r. In Dziennik Ustaw, 2015, poz. 2035.

pap, ss: Tusk: abonament rtv to haracz. In Wprost, 29. 04. 2008.

Postanowienie Prezydenta Rzeczypospolitej Polskiej z dnia 17 czerwca 2015 r. o zarządzeniu ogólnokrajowego referendum. In Dziennik Ustaw, 2015, poz. 852.

Referendum poniosło klęskę. [online]. Available at <http://buzz.gazeta.pl/buzz/56,156947,18721774,referendumponioslo-kleske-tak-na-to-zapatruja-sie-uzytkownicy.html>. [q. 19. 10. 2017].

Referendum poniosło klęskę. [online]. Available at <http://buzz.gazeta.pl/buzz/56,156947,18721774,referendumponioslo-kleske-tak-na-to-zapatruja-sie-uzytkownicy.html>. [q. 10. 10. 2017].

Referendum. Najlepsze memy. [online]. Available at <https://www.wprost.pl/galeria/7231/Referendum-Najlepszememy.html>. [q. 16. 10. 2017].

Referendum. Najlepsze memy. [online]. Available at <https://www.wprost.pl/galeria/7231/5/Referendum-Najlepszememy.html>. [q. 15. 10. 2017].

Referendum. Najlepsze memy. [online]. Available at <https://www.wprost.pl/galeria/7231/11/Referendum-Najlepszememy.html>. [q. 10. 10. 2017].

Reprezentacja nie zawodzi. [online]. Available at <https://demotywatory.pl/4546584>. [q. 16. 10. 2017].

Umorzono śledztwo w sprawie koncertu Madonny na Stadionie Narodowym. [online]. Available at <http://www.rmf24. pl/fakty/polska/news-umorzono-sledztwo-ws-koncertu-madonny-na-stadionie-narodowym, nId,1451341\#utm_ source=paste $\&$ utm_medium=paste $\&$ utm_campaign=firefox $>$. [q. 19. 05. 2017].

Ustawa z dnia 21 kwietnia 2005 r. o opłatach abonamentowych. In Dziennik Ustaw, 2014 r. poz. 1204.

ZIELIŃSKI, E. Referendum w państwie demokratycznym. In WANIEK, D., STASZEWSKI, M. T. (ed.): Referendum w Polsce współczesnej. Warszawa: ISP PAN, 1995, p. 9.

Zmarnowane pieniądze [online]. Available at <https://demotywatory.pl/4546075/Aska-Mucha-(PO)--Zmarnowanepieniadze-Moglam-zorganizowac-za-to-20-koncertow-Madonny>. [q. 14. 10. 2017].

\section{Contact information:}

Prof. Maria Marczewska-Rytko

m_marczewska@yahoo.com

Maria Curie-Skłodowska University in Lublin

Faculty of Political Science

Plac Litewski 3

20-080

Lublin

Poland 